\title{
Do Local Governments Save and Spend across Budget Cycles? Evidence from North Carolina
}

\author{
Wen Wang \\ Assistant Professor \\ Department of Public and Social Administration \\ City University of Hong Kong \\ Tat Chee Avenue, Kowloon, Hong Kong \\ Tel: 852-3442-8273 Email: wenwang@gmail.com \\ Yilin Hou \\ Stanley W. Shelton Professor of Public Finance \\ Department of Public Administration and Policy \\ School of Public and International Affairs \\ University of Georgia \\ Baldwin 204, Athens, GA30602-1615 \\ Tel: 706-542-4705 Email: yihou@uga.edu
}

Wang, W., \& Hou, Y. (2012). Do local governments save and spend across budget cycles? Evidence from North Carolina. The American Review of Public Administration, 42(2), 152-169. http://dx.doi.org/10.1177/0275074011398387 


\title{
Do Local Governments Save and Spend across Budget Cycles? Evidence from North Carolina
}

\begin{abstract}
The fiscal crisis encountered by state-local governments since 2008 has again made prominent the issue of how to better prepare for and stabilize expenditures during recessions. Does the economic stabilization function of government, and its theory, still hold? Previous studies focus on federal and state levels; only a few look at local governments. This article explores whether localities save and spend across the boom-bust cycle; we intend to identify determinants of local government savings and estimate the impact of savings on stabilizing expenditures. Unlike some early evidence that shows counter-cyclical stabilization properties of local unreserved general fund balance, the empirical results of our study on North Carolina counties do not support the stabilization role by localities. This study carries timely and important implications for state/local policy making and financial operations; it also adds to the literature on the stabilization function of government.
\end{abstract}

Keywords: local financial management, fund balance policy, stabilization function of government 


\section{Do Local Governments Save and Spend across Budget Cycles? Evidence from North Carolina}

\section{Introduction}

Since the pioneering work of John Maynard Keynes in 1936 and especially the publication of Richard Musgrave's Theory of Public Finance in 1959, the economic stabilization function of government has been gradually and widely accepted; but counter-cyclical spending was assumed to be the sole responsibility of the national government in the standard Musgrave theory (Musgrave 1959; Oates 1972). Later, Edward Gramlich (1987) advocated pursuing counter-cyclical policies for stabilizing expenditures at the subnational level (Hou and Moynihan 2008). In the past two decades, public finance scholars have produced a rich literature that addresses key questions concerning the adoption, use, and consequences of budget stabilization funds, reserve funds, and other subnational fiscal stabilization tools, with almost an exclusive focus on the state level (Marlowe 2005). Empirical research offers support for the positive impact of counter-cyclical spending on fiscal stress at the state level (Douglas and Gaddie 2002; Hou 2003a, 2005; Sobel and Holcombe 1996; Wagner and Elder 2005). Even though the political economy of the past several decades has implicitly ascribed both state and local governments an important role in the stabilization function (Marlowe 2005), so far we know very little about the practice of counter-cyclical spending at the local level. Only a few studies in the literature looked at the role of local slack resources, either in the form of fund balances or stabilization funds, in local government finance and their impact on decisions about spending and revenues (Gianakis and Snow 2007; Hendrick 2006; Hou 2008; Marlowe 2005).The recent fiscal crisis has again brought the attention of academics and practitioners to the issue of how to better prepare for, and stabilize expenditures in, an economic downturn. Therefore, it becomes 
even more urgent than before to examine whether local governments possess the policy inclination, fiscal capacity, and policy tools to act counter-cyclically, because federal and state governments often cut their grants to localities in an economic downturn (or cannot provide as much as localities need, as in the most recent stimulus package).

The state of North Carolina offers a good case for us to examine the validity of the economic stabilization theory of local government. As a consequence of its rampant local government default on their municipal bonds during the Great Depression, ${ }^{1}$ North Carolina developed a state oversight system that is considered a model by bond rating agencies. Because of the financial discipline of its local governments and effective state oversight and technical assistance, North Carolina leads the nation in the number of local governments with the highest bond rating (Coe 2007). Though 90 percent of states have adopted budget stabilization funds as a formal counter-cyclical fiscal policy instrument (NASBO 2007), budget stabilization funds remains rare among local governments; they rely mostly on year-end balances of the general fund. ${ }^{2}$ This study attempts to examine the practices of such an exemplary system in managing local government fund balances and thereby adds to the small literature on counter-cyclical fiscal and budgetary policies at the local level. The empirical results of this study may carry timely and important implications for policy making and financial operation in the state and local sector.

To operationalize this study, we choose to focus on two research questions: First, what factors affect the level of general fund balances in county governments (in North Carolina)? Second, what is the impact of general fund balances on local expenditures ${ }^{3}$ in general and their stabilizing effects during economic downturns in particular? The two research questions cover two sides of the same issue. Whether the balance of a locality's general fund is large or small in level and ratio, presumably there is an implicit policy behind the balance. By identifying the 
determinants of general fund balance, we can estimate the separate effects of revenue sources, local government programs, and socio-economic factors on the fund balances; then we estimate the effects of fund balances on local expenditures. Thus, we evaluate whether local governments exercise the stabilization role through fiscal policy.

This paper is divided into seven sections. Following the introduction is a brief description of the budget stabilization theory and local fund balance policy. The third section introduces North Carolina counties' finance structure and their fund balance policy. The fourth section reviews current literature on counter-cyclical expenditure stabilization at the local level, followed by a presentation of model specification, data, and estimation methodology. The sixth section presents empirical results with our interpretation, and the final section concludes with a discussion.

\section{Budget Stabilization and Local Fund Balance Policy}

The study of economic stabilization by government emerged with the ground-breaking work of John Maynard Keynes in 1936. Scholars have since studied how central governments could adopt counter-cyclical monetary and fiscal policies to best deal with financial crisis in order to achieve economic stability over the business cycle (Hou 2003b). The economic stabilization function of government has been gradually and widely accepted with the publication of Richard Musgrave's Theory of Public Finance in 1959. Counter-cyclical fiscal policy has, however, been assumed to be the sole responsibility of the central government in the standard (or conventional) Musgrave theory (Musgrave 1959; Oates 1972). Edward Gramlich (1987) expanded the idea of practicing counter-cyclical fiscal policies to subnational governments (Hou and Moynihan 2008). Gramlich observed that the conventional wisdom that only central 
governments should conduct fiscal stabilization policy might have been seriously misguided because empirical studies have shown that the migration of production factors are slow and limited in the short run; therefore, states should practice fiscal policies to stabilize their budgets. In a recession, a subnational government could resort to capital markets or use intergovernmental grants to implement a counter-cyclical fiscal policy. However, intergovernmental grants are often unreliable when grantor governments are also in fiscal distress. Incurring public debt in economic downturns is technically sound; but drastic fiscal measures by state-local governments in bust years to balance their budget often adversely affect their credit rating, thus eroding their borrowing capacity on the capital market. Constitutional or statutory debt limitations also impose constraints on how much governments can borrow. Therefore, the only reliable means a subnational government could resort to in a recession is its fiscal reserves accumulated in boom years (Hou 2003b).

The literature on fiscal federalism also touches upon the issue of what role the central government should play in providing "insurance" against exogenous shocks of various sorts in the intergovernmental fiscal system. When state and local governments subjected to balancedbudget constraints are forced to cut spending in fiscal distress, it makes sense for the central government to provide some fiscal assistance so that they can maintain their level of spending. Indeed several scholars argued that the most effective countercyclical program would be one of federal assistance to state and localities in the context of recent recessions. However, centrally provided insurance to state and local governments comes at a price due to an obvious moral hazard problem. The availability of central insurance may create an adverse incentive for state and local governments not to make sensible provision for time of financial difficulties. They may always expect the central government to extend its assistance to relieve their fiscal distress from 
all sorts of causes. This could create a rationale for fiscal bailouts and a general softening of budget constraints (Oates 2005). Here the fundamental challenge is in the design of fiscal institutions and budgetary procedures that address these incentive problems in ways that create hard budget constraints for state and local governments.

State and local governments accumulate reserves via either formal or informal vehicles. The formal means of saving is by budget stabilization funds, popularly called "rainy day funds," which are created as a result of policy design. The finance law in most states usually includes stipulations regarding the deposits of previous-year budget surplus into the budget stabilization fund (Hou 2004). States vary a lot in whether they allow local governments to create their budget stabilization funds. Some states allow their local governments to formally create budget stabilization funds, but others do not (Hou 2008). The informal vehicle refers to resources accumulated in the general fund, other governmental funds, and enterprise funds that can be used for expenditure stabilization across business cycles (Marlowe 2005). At the local level, formal saving devices are not as widely used as by the states (Hou 2008).Local governments rarely establish a separate budget stabilization fund, relying more on the informal form of fiscal reserves, such as unreserved general fund balances (Marlowe 2005). North Carolina counties, for instance, do not preserve rainy day funds. This study focuses on year-end balances of the general fund to test our research questions.

State governments and other stakeholders have a great interest in monitoring the fiscal conditions of their local governments. When local governments face severe fiscal distress, they may not be able to make timely payments to bondholders, vendors, and/or employees. They may also have to significantly cut back the provision of some essential local public services, creating a very visible and undesirable situation. Meanwhile, current and potential residents and 
businesses may face an increasing tax burden because local governments attempt to generate sufficient revenue to deal with the financial difficulties. In addition, the negative impact goes beyond the distressed community. Surrounding areas are sometimes forced to extend their coverage of service delivery to the distressed community without commensurate compensation. The financial difficulties of the distressed local government may hurt not only its own credit rating, but also that of other localities and the state. Finally, all the state's taxpayers may suffer from having to pay for grants and/or bailouts to the distressed community (Kloha, Weissert and Kleine 2005).

Therefore, probably no other single item in a local government's financial statements attracts more attention than fund balance (Gauthier 2009a), which is the difference between the assets and liabilities reported in the financial statements by the end of each fiscal year, ${ }^{4}$ as it is often used as an indicator to evaluate local fiscal health. State governments use fund balance as one of the major indicators to identify financially distressed local governments so state and local actions can be taken to restore financial stability (Kloha, Weissert and Kleine 2005). Credit rating agencies often assess state and local governments' creditworthiness based on the levels of their fund balance and unreserved fund balance in a government's general fund. Similarly, laws and regulations also govern the appropriate levels of fund balance and unreserved fund balance for state and local governments (GFOA 2002).

The Government Finance Officers Association (GFOA) recommends that state and local governments establish a formal policy on the level of unreserved fund balance that should be maintained in the general fund. The unreserved fund balance is expected to safeguard against the effects of unanticipated natural disasters and economic downturns and to help stabilize tax and 
fee rates and public service levels (Shelton and Tyer 2000; Coe 2007). Fund balance levels are also a crucial consideration in long-term financial planning (GFOA 2002).

In practice, state and local governments often formulate a fund balance policy that establishes a minimum level at which fund balance is to be maintained. GFOA recommends that unreserved general fund balance should represent no less than five to 15 percent of general operating revenues, or no less than one to two months of general fund operating expenditures (Gauthier 2002). A minimum of five percent of unreserved fund balance is recommended by GFOA for larger, in particular state, governments because larger governments often have diversified and less volatile revenues and operating expenditures and normally find it easier to predict contingencies than do smaller ones (Joyce 2001; Hou 2004). Meanwhile, a number of reasons could justify a significantly higher minimum target level for local governments, including significant volatility in operating revenues or expenditures, exposure to natural disasters, rapidly growing budgets, or disparities in timing between revenue collections and expenditures (Gauthier 2009b).

\section{North Carolina Counties}

This study uses counties as the unit of analysis because they are the front-liners in public service provision and the dominant form of local government in North Carolina. Benton (2002) suggests that counties have "become full-service governments" and "are also beginning to rival municipalities as major providers of services that traditionally have been dominated by cities" ( $\mathrm{p}$. 466). Counties in southern states have traditionally held all kinds of responsibilities as a "strong unit performing a large number of functions" (p. 19). They have fewer competing local 
government structures than in other regions of the country, thereby becoming the dominant form of local government (Marando 1979, p. 414).

Several features distinguish counties in North Carolina from those in other states. First, in North Carolina almost all local governmental responsibilities rest with counties (and cities). The majority of local expenditures are also made through counties (and cities), rather than through special districts, school districts, and authorities, which are relatively much more important in many other states. Second, local responsibilities for a number of major "people" services, such as public health, education, and welfare, rest mainly with counties in North Carolina rather than with cities or special districts as in other states, and the county commissioners have limited discretion in whether or how much to fund these services. Third, county governments in North Carolina have more extensive authority than those in other states to provide urban type of services such as water and sewer services, solid waste collection and disposal, and fire protection etc. Finally, North Carolina has a state-local revenue system that relies mainly on four major taxes- property, general sales, individual and corporate income, and gasoline. Rates for the sales and income taxes are relatively high in comparison to the same type of taxes in other states, whereas rates for the property tax are low compared to those in other jurisdictions. Since the property tax is relatively less important in North Carolina than it is in other states, whereas income and sales taxes have greater significance, the revenue structure of North Carolina tends to be more sensitive than that of most states to fluctuations in the economy (Bell 2007).

North Carolina has a long tradition of using professional managers in local governments (Stenberg 2007) ${ }^{5}$ and has developed a conservative budgeting and financial management system after the Great Depression. The legislature created a Local Government Commission (LGC) under the State Treasurer's Office to impose financial controls and assist local governments in 
trouble. North Carolina is the only state that is legally responsible for issuing all local debt (Shelton and Tyer 2000; Coe 2007). The LGC recommends that localities maintain a minimum unreserved fund balance of 8 percent of annual expenditures, and retain a much higher amount of fund balances (Coe 2007). The LGC also proactively works with local governments to resolve their identified financial problems.

\section{Literature Review}

The existing literature on budget stabilization focuses on federal and state governments; only in recent years did some scholars begin to pay attention to the local level. We review this literature in two sub-areas that are related to this paper: determinants of fund balance and effects of the saved balances.

\section{Determinants of the Size of Unreserved Fund Balance}

The Government Finance Officers Association (GFOA) recommends 5-15 percent as the benchmark of state-local savings; but previous studies found localities do not seem to show the same propensity to limit their savings as states do and that localities maintain much higher levels. Minnesota cities $(n=103)$ kept an average 53 percent of their current expenditures as general fund balance in the 1990-2000period. The fund balance was more than needed for cash flow purposes in over half of the cities, and was equal to or more than a full year's current expenditures in 20 percent of them(Marlowe 2005). Chicago suburban municipalities kept a median 53 to 66 percent of unreserved fund balance from 1997 to 2003 (Hendrick 2006). Most Mississippi counties maintained an unreserved fund balance ranging from 25 to 237 percent of their expenditures in 1995 and 1999 (Stewart 2009). 
Only a few studies attempted to explain the factors that determine the size of unreserved fund balance at the local level; and they reached no consensus. Hendrick (2006) found current fiscal performance, indicated as operating deficits or surplus, had a strong effect on municipal fund balances. She also found that debt levels had a negative impact: The higher the level of municipal debt was, the less reserves were used to fund capital expenditures. Size was another factor: Larger governments appeared to accumulate less reserves than smaller ones. Municipalities that were more politically conservative, reformed, and professional tended to accumulate more reserves. Not surprisingly, wealthier municipalities with lower spending needs had higher reserves than those that were poor and had higher spending needs. Hendrick's analysis demonstrated that the main purpose of reserves was to cushion for unpredictable events and short-run instability. Unreserved fund balances became more important and interchangeable during fiscal downturns while maintaining reserves to compensate for risks became less important.

Stewart (2009) also found that current fiscal condition significantly influenced the level of Mississippi counties' unreserved fund balances during two periods of relative resource abundance and scarcity. The only variable of significance during both periods was debt level, which had a negative impact on unreserved fund balance. Other fiscal, demographic, and political variables included in the study explained little variation in fund balances, which may suggest that Mississippi counties were unique within themselves and it was hard to identify common factors to explain the behavior of unreserved fund balance.

Thus, it seems that applying a 5-15 percent savings benchmark across all jurisdictions does not provide a sufficient guide when localities assume different patterns in accumulating 
savings. Future research on this topic may need to focus on other variables to explain the behavior of unreserved fund balances.

\section{The Effects of Unreserved Fund Balance on Government Expenditures}

Studies of fiscal reserves at the state level find strong evidence that state savings help to maintain the level of government spending during downturn years (Sobel and Holcombe 1996; Hou 2003a, 2005). Few studies, however, provide direct evidence about the effects of unreserved fund balance on the stabilization of government expenditures at the local level. Marlowe (2005) examined whether local slack fiscal resources in the form of general fund balance had similar counter-cyclical effects; he found that municipal fiscal reserves in general had a marginal impact on the direction and size of current expenditure gaps, but unreserved general fund balance posed a counter-cyclical stabilizing effect.

Hendrick (2006) found some significant, positive impact of unreserved fund balance on the percentage change of expenditures with pooled data for Chicago suburban municipalities, but the results were not reliable for individual years. The analysis suggests that municipal fiscal slack has “a fairly complex relationship with governments' other fiscal structural features and environment," which makes it difficult to detect the effects of fiscal slack on alleviating fiscal distress. Future research should attempt to develop a "theoretical model that incorporates relevant managerial, organizational, and political features...” (p. 43).

Hou (2008) investigated the determinants of the size of local fund balances and the impact of fund balances on local expenditures in downturn years. He suggested a number of parameters for the analysis of local governments' fiscal behavior in economic fluctuations, including states' permission for their localities to create their own rainy day fund, local 
governments' adoption of a formal or informal counter-cyclical fiscal policy, and revenue portfolio and professionalism of local governments. The empirical results of the study based on Georgia County data showed that local governments had few alternatives other than coping during economic downturns, given their less diversified revenue portfolio and strict balanced budget requirement. This study continues on Hou's (2008) exploration.

\section{Model Specification, Data, and Methodology}

Following the empirical framework adopted by previous research, we conduct empirical analysis to examine the factors that affect the level of general fund balances in North Carolina counties and the impact of these balances on county general fund expenditures in general and their stabilizing effects during economic downturns in particular, using a dataset of all the 100 counties in North Carolina for the period of 1990-2007. Since the sample period covers two most recent, full business cycles, point estimates thus obtained may bear more directly to current practices in local governments.

\section{Dependent Variables}

To identify determinants of fund balances (answer our first research question), we use two dependent variable: fund balance and the balance as a share of overall expenditures. To estimate the effects of the balance (the second research question), our dependent variables are total expenditure, and year-to-year change (first difference) of total expenditure. To evaluate expenditure fluctuations, we construct an expenditure gap variable as the difference between actual expenditures and expenditures projected from a linear trend. Following previous studies, county expenditures are predicted as below:

$$
E_{i t}^{*}=a_{i}+b_{i} T
$$


where $E_{i t}^{*}$ is the predicted expenditure for county $i$ in year $t, a_{i}$ the constant for county $i, b_{i}$ the linear trend coefficient for county $i$, and $T$ the value of the year in year $T$. Then the expenditure gap is expressed as the difference between the actual and the predicted expenditures as a percentage of the predicted expenditure:

$$
\text { Expenditure Gap }=\frac{E-E^{*}}{E^{*}}
$$

Positive expenditure gaps are expected in boom years, whereas negative expenditure gaps may arise during economic downturns.

\section{Explanatory Variables}

To investigate the first research question, we choose five groups of explanatory variables: revenues, expenditures, economic indicators, social indicators, and county size. Revenue variables include the major revenue sources for county governments; these are property tax, sales tax, and intergovernmental revenue. Prior research indicates that the composition of governments' revenue sources determines the stability of their revenue and in turn the level of their fund balance. Governments could plan on stable revenue sources more than on cyclical ones, e.g. fines and fees (Stewart 2009). In contrast, they may have to use the unreserved fund balance to smooth the tax rate and offset erratic revenue fluctuations (Massey and Tyer 1990; Stewart 2009). Therefore, stable revenue sources would help governments to accumulate a higher level of fund balance (Marlowe 2005; Stewart 2009). Since property tax and local option sales taxes are the two most important revenue sources for North Carolina counties (though sales taxes are more prone to business cycle fluctuations), they are expected to facilitate maintaining fund balance. Intergovernmental grants to the county are more volatile because federal and state governments are likely to cut grants when they are under fiscal distress. Previous studies posited that local 
governments would accumulate more fiscal slack as a shield against revenue shocks if they have a heavier reliance on intergovernmental grants (Hendrick 2006; Stewart 2009). However, the negative relationship found between grants and fund balance suggests that local governments might not recognize the risk involved in relying on such a revenue source (Stewart 2009) or that they might not have the capacity to cushion against such cuts that lead to unavoidably reduced local revenues.

County expenditures by function include expenditures for salaries and wages, capital outlays, and other operating purposes. Hendrick (2006) suggested that the levels of capital spending and total government spending, as measures of alternative sources of slack or fiscal flexibility, should have a negative impact on fund balance. In this study, we test the effects of different categories of spending on unreserved fund balance. Data for all the above-mentioned financial variables were collected from the Annual Financial Information Forms issued by the State Treasurer's Office in various years.

We include county per capita income and unemployment rate as the third group of explanatory variables to capture the effects of economic factors on our dependent variables. As suggested by previous studies (Stewart 2009; Wagner 2003), we expect per capita income to be positively correlated with unreserved fund balance and unemployment rate negatively correlated. The income data are obtained from the U.S. Bureau of Economic Analysis; the unemployment rate data are from the U.S. Bureau of Labor Statistics.

Social indicators are the size of population, population squared, and shares of the schoolage and the senior groups in the population, obtained from the North Carolina Office of State Budget and Management. Racial and ethnic diversity and the number of eligible people entitled 
to retirement may influence the behavior of the fund balance (Marlowe 2004; Stewart 2009); but such data are not available. Finally, we construct three dummy variables of county size by population to test the effects of the size of a jurisdiction on our dependent variables. The county size dummies were constructed according to the classification of the North Carolina Treasurer's Office that roughly divides the 100 counties into four groups by their size of population; there are around 25 counties in each group.

We test the effects of fund balances on county expenditures and expenditure gaps. Fund balances are expected to have a positive impact on total expenditures. If fund balances have a positive impact on the expenditure gap during downturn years, they can be said to have a counter-cyclical effect. In contrast, they may have a procyclical effect if they increase a positive expenditure gap in booming years or enlarge a negative expenditure gap in lean years (Marlowe 2005).

Revenue sources, economic indicators, social indicators, and county size variables are also included in the models. Higher tax revenues are expected to lead to higher expenditures. The effects on the expenditure gap depend on their stability over the business cycle. Grants are also an important variable because they may create cash flow problems that can be addressed only by accumulating more adequate fund balances by local governments (Marlowe 2005). This study includes this variable to test its potential effects on county expenditures and expenditure gaps. Income and unemployment are included in the models to capture the variability in county economic conditions. The four social indicators are used to test their effects on the spending decisions of county governments. County size dummies are also included as controls. Table 1 provides the descriptive statistics of all variables included in this analysis. 
[Table 1 here]

To answer our first research question, we estimate two regression models; per capita fund balance and fund balance share are regressed on the above-mentioned five groups of independent variables. To address the second research question, we estimate several empirical models to explore the effects of fund balances, both in level and ratio, on total county expenditures, the first difference of total expenditures, and expenditure gaps over the business cycle.

\section{Estimation Methodology}

We use the Newey-West estimator to deal with heteroskedasticity and autocorrelation in the dataset. OLS estimates are computed, and standard errors adjusted for heteroskedasticity and autocorrelation. We also add in county fixed effects in the model to control for time-invariant unobservable factors, and year fixed effects to control for yearly statewide changes. ${ }^{6}$

As certain county-specific characteristics may have differential effects on county expenditure gaps in various years, we estimate a Heckman two-stage selection model to address the potential selection bias. Population growth may create differential impact on individual county governments given the specific context of each county. Changes in debt service could affect the current revenues available depending on individual county debt service schedules and capital improvement plans (Marlowe 2005). In addition, the differences in the composition of revenue portfolio may also affect a county's capacity in adjusting to the changes in its economic conditions. Therefore, population growth, changes in debt service, and shares of property tax, sales tax, and intergovernmental revenue are included in the first-stage to estimate the likelihood for a county to experience a downturn year or upturn year.

\section{Empirical Results}




\section{Determinants of General Fund Balances}

Results on the determinants of fund balances, both in level and in ratio, are presented in Table 2. Among the major revenue sources, property tax exerts a statistically significant influence - each dollar of revenue from this source can raise balances by 35 cents or 0.05 percentage points. Given the average level of fund balances of 96 dollars or 22 percent of total expenditure, the 205 dollar average from this source can increase fund balances by 72 dollars, a three-quarters increase in level, or 11 percentage points, a 50 percent increase in ratio. Also statistically significant is revenue from the sales tax, for which the magnitude is particularly large: Each dollar from this source can boost fund balance by as much as 1.36 dollars in level or 0.16 percentage points. In other words, the 79 dollar average sales tax revenue can raise fund balances by 107 dollars, more than double the fund balances, or 12 percentage point, also an over 50 percent increase. Intergovernmental revenue does not pose a significant effect, probably because these grants all come with a specified purpose for use in the current fiscal year so that they do not add much to year-end balances.

[Table 2 here]

Among the major expenditure categories, only capital outlay posts a statistically significant, negative effect in the ratios model: Each dollar of outlay reduces the fund balance by 0.014 percentage points; thus an average county with 45 dollars outlay in this category will have their fund balanced cut by 0.63 percentage points, which is only a 2.8 percent reduction off the average balance ratio, not a remarkable size. The two economic indicators are both significant (marginally significant in the level model), with the expected sign. Wealthier counties tend to have more in their year-end fund balances, both in the level and the ratio form. Per thousand dollar increase in per capita personal income can raise fund balance by 4.6 dollars or 0.91 
percentage points. An average county with their personal income at the 12,929 dollar level can expect to have about 60 extra dollars in their balance or over 11 percentage points above the average 22 percent level; thus, this wealth effect is quite substantial. Higher unemployment rates pulls down fund balances, each percentage point by 1.5 dollars in level or 0.44 percentage points in ratio. An average county in an average year (with the unemployment rate at 5.73) may expect a fall of close to 9 dollars in level or 2.57 percentage points.

Of the social indicators, the shares of the young and the old in total population do not generate statistically significant results. Population size points to economies of scale - larger counties tend to maintain smaller fund balances in ratio; that is, the size of a locality matters in the negative direction. This effect, however, is not linear, as indicated by the positive sign of the quadratic term of this variable. The county size dummies are not significant; potentially the population variable may have picked up the effect. We tried removing these dummies but obtained no observable, statistically significant difference.

\section{Effects of Fund Balances on Expenditures}

We then test the effects of previous year fund balances (t-1) on total expenditures. The dependent variables are per capita real expenditure and the first difference (annual change) in total expenditure, thereby making the interpretation of the results straightforward. Results of this test are shown in table 3.

[Table 3 here]

Fund balances carried forward from the previous year exert a small but significant effect on total expenditures: Per dollar of balance can increase expenditure by 15 cents, that is about 14 dollars increase for an average county (with a mean of 96 dollars of balance), which is a 2.6 
percent push on the average of 549 dollars of total expenditure. Fund balance as a percent of total expenditure, however, is not statistically significant.

The three major revenue sources all present significant and large effects on total expenditures. Each additional dollar of property tax or intergovernmental grant is associated with an increase of over 80 cents in total expenditures. Of particular interest is the large effect of sales tax revenue on total expenditure: each dollar from this source adds between 3.11 and 3.28 dollars to the expenditure side; however, based on our limited data we cannot yet offer a reasonably satisfactory answer.

The economic indicators and the young and the old shares in the population do not produce significant results. The non-linearity of population size keeps its significance. Total expenditure first rises with size, at 1.54 dollars for per thousand more residents. Then it drops, confirming again the economies of scale. The county size dummies correspond to this finding: All three are negative with two being significant, i.e., all spend less than the small counties. Medium sized (50,000-100,000) and medium-small sized (25,000-50,000) counties are spending between 70 and 75 dollars less per capita than the (default) small $(<25,000)$ counties. This result points again to two issues: First, the county at the front line of service provision shoulders the task of supporting the daily life of residents; large or small, their functions are essential so that being small may in fact push up total expenditures. Second and related to the first, economies of scale is a factor we should not neglect.

Of the annual changes in total expenditure, fund balance as a percent of total expenditure is significant: Every percentage point can account for 83 cents in the marginal increase in total expenditure. The other significant factor is intergovernmental grants, each dollar accounting for about 50 cents of the annual outlay increase. Given the average amount from this source of 126 
dollars, intergovernmental grants can potentially account for 62 dollars, 3.6 times the annual increase. Population and its squared term retain their significance and expected sign in this specification.

\section{Effects of Fund Balances on Expenditures during Downturns}

Our final test is to identify the effects of fund balances on expenditures during the downturn and upturn years of the economic cycle, which can be taken as the local government activity cycle. We do so by decomposing the expenditure gap variable into two groups: Those smaller than 0 are a proxy for the local downturn years and those larger than 0 are a proxy for the

local upturn years. ${ }^{7}$ We use the James Heckman two-stage sample selection estimator for the test. The results are reported in table 4 (results from the first stage are not presented).

[Table 4 here]

The models in general fit well. Given the sample period of this study, the number of observations of downturns (703) is smaller than that in upturns (990), which fits our intuition. We are interested in whether the fund balance variables exert positive impact during the downturn and how they impact the trend during the upturn. In downturns, the balances either in level or in ratio do not pose an effect that is significantly different from zero. Among the revenue sources, only intergovernmental dollars show a significant estimate in both phases of the cycle; that is, during a downturn, the other revenue sources do not seem to play a counter-cyclical role. The magnitude of the grants variable is 0.018 percentage points per dollar, which is about 2.2 percentage points for an average county $(=126 \mathrm{X} 0.018)$, far from enough to raise expenditures up to the trend from the level of the constant (-30 percentage points). The share of seniors in total population shows a significant, positive effect in downturn years at the magnitude of 0.71 in both 
the level and the ratio models. At the mean share of seniors (14 percent), the senior population may reduce the expenditure gap by about 10 percentage points in a downturn. Population size has a similar effect at the magnitude of 0.1 in both specifications, which means the population variable may reduce the gap in downturns by 7.8 percentage points. Again, this effect is not linear; the quadratic term shows a negative effect.

In upturn years when the constant is already above the trend (by 16-19 percentage points), in contrast, the fund balance ratio is statistically significant (the level variable is marginally significant): The balance level can push up the trend further by close to 2 percentage points (96 $\mathrm{X} 0.021=1.97)$ and the balance ratio can send the trend up by about the same range $(22 \times 0.1=$ 2.28). The magnitude of intergovernmental grants nearly doubles (from 0.018 to 0.03 ). Property tax revenue is now also significant at about 0.08 percentage points per dollar, the total effect of which can amount to 16 percentage points for an average county. The socio-economic variables are not significant but all the three county size binaries are significant and negative, that is, the small counties now spend more than their larger counterparts. In sum, we see mainly procyclical forces instead of counter-cyclical ones.

\section{Discussion and Conclusion}

This paper has examined the determinants of local government savings and estimated the effects of these accumulated savings on local expenditures. On the determinants of local savings, we found the property tax is a major contributor; intergovernmental grants are not, because they are for use in the current year. Having local option sales taxes is a strong plus at the local level: It may contribute dollar-for-dollar towards savings. Wealth is also a major savings contributor, indicating a strong positive relation between income and local savings capacity. Capital outlay reduces savings; so does unemployment. The population size of localities presents a nonlinear 
relationship with fund balances - within a certain range, economies of scale exist. Since local governments are at the forefront of public service provision, being small does not necessarily render any advantages but increases outlays.

Using county data in the state of North Carolina in the last two business cycles we have tested cyclical features of local expenditures and found their trend to be procyclical. Unlike some early evidence that suggests counter-cyclical stabilization properties of local unreserved general fund balance, the empirical results of our study do not show that local savings exert countercyclical impact on expenditure. Intergovernmental grants exert a small effect in the downturn but its effect in the upturn is much larger. This finding leads us to more questions for further exploration: If with a sizable ratio of savings localities still do not act counter-cyclically, they are simply following the economic and fiscal tide. The fact that large counties do come closer to the trend in upturn years than small ones do may suggest that being small loses the stand to go against the tide. If that is the case, how do we design fiscal institutions and budgetary procedures that allow the federal or state government to provide more effective fiscal assistance to localities without creating a problem of soft budget constraint?

Our findings carry timely and important policy implications and contribute to the existing literature in several important ways. First, the mere size of savings at the local level is probably not enough to support a counter-cyclical fiscal policy. If this is true, then studies on the optimal size of savings will not shed light on the question. Second, the size of a jurisdiction does matter. Since being small does not render any advantage in this aspect, we should give up any unrealistic expectations for small localities to be fiscally "active" against the business cycle. Let them focus on providing services and not worry about finances. The current study is only among the first explorations, more solid work is to be done with better data. 


\section{Notes}

1. North Carolina had the second highest number of municipal bond defaults during the Great Depression; sixty-two of its 100 counties defaulted on the principal, interest, or both by 1932 (Coe 2007).

2. The general fund is an accounting term, referring to the fund of a government that holds all money that is not specified to other fund types. It is usually the single largest fund of a government, covering most operating outlays.

3. Unless otherwise specified, by "expenditure" we refer to "general fund expenditures" of county governments.

4. In the language of governmental accounting, governmental funds only report a subset of related assets and liabilities; so the difference between assets and liabilities is more a measure of liquidity than net worth. In this sense, general fund balance is very similar to the working capital of a private business.

5. In 1929 Robeson County became the first county in the U.S. to adopt the county-manger form of government. At present 99 of the 100 counties in North Carolina employ a full-time professional county manager (Stenberg 2007).

6. Given the concerns that a county's spending behavior may be affected by spending behavior among counties in the same region, we ran diagnostic tests for spatial autocorrelation in fund balance and expenditure models. The test results did not show a significant effect of spatial autocorrelation in the empirical models.

7. We ran a dynamic fixed-effects model to test the cyclical properties of the expenditure gap by regressing it against the annual (first difference) change in per capita total current revenue and its lags from one to five years. The results show that the expenditure gap is procyclical; it is positively correlated with the annual change in county revenue. 


\section{References}

Bell, II, A Fleming. 2007. Article 1: An Overview of Local Government. In County and Municipal Government in North Carolina, edited by D. M. Lawrence, Chapel Hill, NC: UNCChapel Hill. Available at http://www.sog.unc.edu/pubs/cmg/.

Benton, J. Edwin. 2002. Counties as Service Delivery Agents: Changing Expectations and Roles. Westport, CT: Praeger Publishers.

Coe, Charles K. 2007. Preventing Local Government Fiscal Crises: The North Carolina Approach. Public budgeting \& Finance, 27(3): 39-49.

Douglas, James W., and Ronald K. Gaddie. 2002.StateRainy Day Funds and Fiscal Crises: Rainy Day Funds and the 1990-1991 Recession Revisited. Public Budgeting \& Finance 22:19-30.

Gianakis, G., and Snow, D. 2007. Implementation of Local Government Stabilization Funds in Massachusetts. Public Budgeting \& Finance, 27 (1): 86-103.

Gauthier, Stephen J. 2002. Reserve Fund Balance Policy Promulgated. American City \& County, 117(4): 6

. 2009a. Fund Balance: New and Improved. Government Finance Review. See www.gfoa.org/downloads/NewFundBal_GFR_apr_09.pdf.

. 2009b. What Everyone Needs to Know about the New Fund Balance? Chicago:

Government Finance Officers Association (GFOA).

Government Finance Officers Association (GFOA). 2002. Appropriate Level of Unreserved Fund Balance in the General Fund. See www.gfoa.org/downloads/budget-appropriate.pdf. Gramlich, Edward M. 1987. Subnational Fiscal Policy. In Perspectives on Local Public Finance and Public Policy, edited by John M. Quigle, 3-27. Greenwich, CT: JAI Press Inc.

Hendrick, Rebecca. 2006. The Role of Slack in Local Government Finances. Public Budgeting \& Finance, 26(1): 14-46.

Hou, Yilin. 2003a. What Stabilizes State General Fund Expenditures in Downturn Years-Budget Stabilization Fund or General Fund Unreserved Undesignated Balance? Public Budgeting \& Finance, 23(2): 64-85.

. 2003b. Budget Stabilization Fund. In Encyclopedia of Public Administration and Public

Policy, ed. Jack Rabin. New York: Marcel Dekker Press.

2004. Budget Stabilization Fund: Structural Features of the Enabling Legislation and Balance Levels. Public Budgeting \& Finance, 24(3): 38-64. 
2005. Fiscal Reserves and State Own-Source Expenditure in Downturns. Public Finance Review, 33(1): 117-144.

. 2008. Parameters of Local Government Options for a Downturn: Evidence from Georgia Counties. Paper presented at the 2008 Annual Conference of the Association for Budgeting and Financial Management (ABFM), Chicago, October 23-25, 2008.

Hou, Yilin and Donald P. Moynihan. 2008. The Case for Countercyclical Capacity. Journal of Public Administration Research and Theory, 18: 139-159.

Joyce, Philip G. 2001. What's So Magical about Five Percent? A Nationwide Look at Factors that Influence the Optimal Size of State Rainy Day Funds. Public Budgeting \& Finance, 21(3): 62-87.

Kloha, Philip, Carol S. Weissert and Robert Kleine. 2005. Someone to Watch Over me: State Monitoring of Local Fiscal Conditions. The American Review of Public Administration, 35(3): 236-255.

Marando, Vincent L.1979. City-County Consolidation: Reform, Regionalism, Referenda, and Requiem. Western Political Quarterly, 32(4): 409-21.

Marlowe, Justin. 2004. The Local Fund Balance: Explanations and Implications. Unpublished doctoral dissertation, University of Wisconsin-Milwaukee.

. 2005. Fiscal Slack and Counter-Cyclical Expenditure Stabilization: A First Look at the Local Level. Public Budgeting \& Finance, 25(3): 48-72.

Massey, Jane and Charlie B. Tyer. 1990. Local Government Fund Balances: How Much is Enough? The South Carolina Forum: A Review of Public Affairs in South Carolina, 1: 40-46.

Musgrave, Richard A. 1959. The Theory of Public Finance. New York: McGraw-Hill.

National Association of State Budget Officers (NASBO). 2007. Fiscal Survey of the States. Washington, DC.

Oates, Wallace E. 1972. Fiscal Federalism. New York: Harcourt Brace Jovanovich. 2005. Toward A Second-Generation Theory of Fiscal Federalism. International Tax and Public Finance, 12: 349-373.

Shelton, Michael and Charlie Tyer (with Holly Hembree). 2000. Local Government Reserve Funds and Fund Balance: Some Applications of Business Concepts. Municipal Finance Journal, 21(1): 1-18. 
Sobel, Russell S. and Russell G. Holcombe. 1996. The Impact of State Rainy Day Funds in Easing State Fiscal Crises during the 1990-91 Recession. Public Budgeting \& Finance, 16(3): $28-48$.

Stenberg, III, Carl W. 2007. Article 5: Leading and Governing in Council-Manager Counties and Cities. In County and municipal government in North Carolina, edited by D. M. Lawrence, Chapel Hill, NC: UNC-Chapel Hill. Available at http://www.sog.unc.edu/pubs/cmg/.

Stewart, La Shonda M. 2009. Examining Factors that Impact Mississippi Counties' Unreserved Fund Balance during Relative Resource Abundance and Relative Resource Scarcity. Public Budgeting \& Finance, 29(4): 45-73.

Wagner, Gary A. 2003. Are State Budget Stabilization Funds only the Illusion of Savings? Evidence from Stationary Panel Data. Quarterly Review of Economics and Finance, No. 43, 21338.

Wagner, Gary A. and Eric M. Elder. 2007. Revenue Cycles and the Distribution of Shortfalls in U.S. States: Implications for an 'Optimal' Rainy-Day Fund. National Tax Journal, 60(4): 727742 . 
Table 1: Descriptive Statistics (NC County Data: 1990-2007)

\begin{tabular}{|l|r|r|r|r|}
\hline \multicolumn{1}{|c|}{ Variable } & Obs & \multicolumn{1}{|c|}{ Mean } & \multicolumn{1}{|c|}{ Min } & \multicolumn{1}{c|}{ Max } \\
\hline Dependent/Key Variables & & & & \\
$\quad$ Fund balance available & 1799 & 95.98 & -49.22 & 839.63 \\
Fund balance available as \% of total expenditure & 1799 & 22.11 & -9.58 & 138.64 \\
First difference of fund balance available & 1799 & 3.12 & -206.10 & 794.64 \\
Expenditure gap (\%) & 1799 & 0.036 & -45.11 & 89.15 \\
Revenue Sources & & & & \\
Property tax & 1799 & 204.94 & 65.19 & 622.19 \\
Sales tax & 1799 & 79.01 & 28.95 & 258.06 \\
Intergovernmental revenue & 1799 & 125.91 & 33.64 & 1134.12 \\
Total revenue & 1799 & 567.63 & 246.73 & 2478.38 \\
First difference of total revenue & 1699 & 15.92 & -1268.66 & 1249.96 \\
\% of property tax in total revenue & 1799 & 37.22 & 10.51 & 58.76 \\
\% of sales tax in total revenue & 1799 & 14.88 & 4.48 & 27.46 \\
\% of intergovernmental revenue in total revenue & 1799 & 22.78 & 3.26 & 58.97 \\
Expenditures & & & & \\
Salaries \& wages & 1799 & 129.54 & 49.23 & 438.09 \\
Other operating expenditures & 1799 & 191.41 & 54.93 & 944.50 \\
Capital outlay & 1799 & 45.22 & 0.30 & 1127.87 \\
Total expenditure & 1799 & 549.28 & 247.98 & 2291.70 \\
First difference of total expenditure & 1799 & 17.05 & -529.69 & 831.67 \\
Debt service expenditure & 1799 & 38.34 & 0.00 & 329.40 \\
Changes in debt service & 1790 & 23.13 & -100.00 & 4425.20 \\
Economic Indicators & & & & \\
Personal income (1,000) & 1799 & 12.93 & 7.86 & 22.02 \\
Unemployment rate (\%) & 1799 & 5.73 & 1.20 & 19.80 \\
Social Indicators & & & & \\
\% of population under 18 & 1799 & 23.74 & 14.95 & 30.99 \\
\% of population over 65 & 1799 & 14.25 & 4.44 & 24.56 \\
Population (1,000) & 1799 & 78.29 & 3.73 & 859.85 \\
Population growth rate (\%) & 1699 & 1.41 & -3.34 & 8.22 \\
County Size by Population (binaries) & 1799 & 0.22 & 0.00 & 1.00 \\
Large (> 100,000) & 1799 & 0.25 & 0.00 & 1.00 \\
Medium (50,000-100,000) & 1799 & 0.24 & 0.00 & 1.00 \\
Medium small (25,000-50,000) & 1799 & 0.28 & 0.00 & 1.00 \\
Small (<25,000) & & & \\
\hline Note: Alf & & & \\
\hline
\end{tabular}

Note: All financial level figures are in per capita real terms. 
Table 2: Fund Balance Models

\begin{tabular}{|c|c|c|c|c|}
\hline & \multicolumn{2}{|c|}{$\begin{array}{c}\text { Fund Balance } \\
\text { Available (FBA) }\end{array}$} & \multicolumn{2}{|c|}{$\begin{array}{c}\text { FBA as \% of Total } \\
\text { Revenue }\end{array}$} \\
\hline & Coefficient & $\mathbf{z}$ & Coefficient & $\mathbf{z}$ \\
\hline \multicolumn{5}{|l|}{ Revenues } \\
\hline Property tax & $0.354 * * *$ & 4.080 & $0.053 * * *$ & 3.151 \\
\hline Sales tax & $1.356 * * *$ & 6.299 & $0.157 * * *$ & 3.545 \\
\hline Intergovernmental & -0.017 & -0.540 & -0.006 & -0.977 \\
\hline \multicolumn{5}{|l|}{ Expenditures } \\
\hline Salaries \& wages & 0.105 & 1.310 & -0.009 & -0.539 \\
\hline Other operating & 0.022 & 0.663 & -0.008 & -1.264 \\
\hline Capital outlay & -0.028 & -0.784 & $-0.014 * *$ & -2.030 \\
\hline \multicolumn{5}{|l|}{ Economic indicators } \\
\hline Personal income $(1,000)$ & $0.005 *$ & 1.694 & 0.001 & 1.556 \\
\hline Unemployment rate & -1.545779 & -1.703 & $-0.438 *$ & -1.962 \\
\hline \multicolumn{5}{|l|}{ Social indicators } \\
\hline$\%$ of population under 18 & -0.841 & -0.303 & 0.016 & 0.025 \\
\hline$\%$ of population over 65 & 3.572 & 1.060 & 0.153 & 0.219 \\
\hline Population $(1,000)$ & $-0.336 * *$ & -1.234 & $-0.144 * *$ & -2.065 \\
\hline Population squared & $0.000^{* * *}$ & 0.774 & $0.0001 *$ & 1.822 \\
\hline \multicolumn{5}{|l|}{ County size } \\
\hline Large & 13.926 & 0.894 & 5.602 & 1.625 \\
\hline Medium & 2.794 & 0.233 & 2.312 & 0.947 \\
\hline Medium small & -12.118 & -1.166 & -2.236 & -1.162 \\
\hline No. of observations & \multicolumn{2}{|l|}{1799} & \multicolumn{2}{|l|}{1799} \\
\hline Prob $>F$ & \multicolumn{2}{|l|}{0.000} & \multicolumn{2}{|l|}{0.000} \\
\hline Centered R-squared & \multicolumn{2}{|l|}{0.269} & \multicolumn{2}{|l|}{0.082} \\
\hline
\end{tabular}

Note: Significance levels are: $* * * p<0.01,{ }^{* *} \mathrm{p}<0.05,{ }^{*} \mathrm{p}<0.1$ 
Table 3: Effects of Fund Balances on Total Expenditure

\begin{tabular}{|c|c|c|c|c|c|c|c|c|}
\hline & \multicolumn{4}{|c|}{ Total Expenditure } & \multicolumn{4}{|c|}{ First Difference of Total Expenditure } \\
\hline & Co-ef & $\mathbf{Z}$ & Co-ef & $\mathbf{z}$ & Co-ef & $\mathbf{Z}$ & Co-ef & $\mathbf{z}$ \\
\hline $\begin{array}{l}\text { Fund balance available }_{t-1} \\
\% \text { of fund balance available } e_{t-1}\end{array}$ & $0.146 * *$ & 2.063 & 0.322 & 1.336 & 0.080 & 0.883 & $0.829 * *$ & 2.272 \\
\hline \multicolumn{9}{|l|}{ Revenue sources } \\
\hline Property tax & $0.824 * * *$ & 4.718 & $0.841 * * *$ & 4.743 & 0.164 & 0.965 & 0.182 & 1.068 \\
\hline Sales tax & $3.114 * * *$ & 4.558 & $3.277 * * *$ & 4.706 & 0.480 & 0.888 & 0.459 & 0.858 \\
\hline Intergovernmental & $0.859 * * *$ & 6.350 & $0.858 * * *$ & 6.368 & $0.487 * * *$ & 3.772 & $0.495 * * *$ & 3.845 \\
\hline \multicolumn{9}{|l|}{ Economic Indicators } \\
\hline Personal income $(1,000)$ & 3.875 & 0.795 & 4.427 & 0.905 & 2.947 & 0.690 & 2.454 & 0.574 \\
\hline Unemployment rate & -2.096 & -1.045 & -2.082 & -1.032 & 0.589 & 0.274 & 0.792 & 0.370 \\
\hline \multicolumn{9}{|l|}{ Social Indicators } \\
\hline$\%$ of population under 18 & -3.553 & -0.731 & -3.995 & -0.821 & -1.253 & -0.259 & -1.419 & -0.293 \\
\hline$\%$ of population over 65 & 6.244 & 0.919 & 6.627 & 0.974 & 7.208 & 1.100 & 7.056 & 1.085 \\
\hline Population $(1,000)$ & $1.541 * *$ & 2.395 & $1.539 * *$ & 2.410 & $1.172 * *$ & 2.233 & $1.226 * *$ & 2.328 \\
\hline Population squared & $-1.085 * *$ & -2.288 & $-1.095 * *$ & -2.328 & $-0.902 * *$ & -2.371 & $-0.936 * *$ & -2.457 \\
\hline \multicolumn{9}{|l|}{ County Size(binaries) } \\
\hline Large & -56.794 & -1.475 & -56.410 & -1.450 & 13.805 & 0.423 & 7.221 & 0.221 \\
\hline Medium & $-75.072 * *$ & -2.324 & $-75.234 * *$ & -2.298 & 23.716 & 0.913 & 19.475 & 0.751 \\
\hline Medium small & $-69.458 * *$ & -2.420 & $-70.736 * *$ & -2.428 & 4.475 & 0.221 & 3.881 & 0.192 \\
\hline No. of observations & \multicolumn{2}{|l|}{1699} & \multicolumn{2}{|l|}{1699} & \multicolumn{2}{|l|}{1699} & \multicolumn{2}{|l|}{1699} \\
\hline Prob $>F$ & \multicolumn{2}{|l|}{0.000} & \multicolumn{2}{|l|}{0.000} & \multicolumn{2}{|l|}{0.000} & \multicolumn{2}{|l|}{0.000} \\
\hline Centered R-squared & \multicolumn{2}{|l|}{0.612} & \multicolumn{2}{|l|}{0.610} & \multicolumn{2}{|l|}{0.105} & \multicolumn{2}{|l|}{0.110} \\
\hline
\end{tabular}

Note: Significance levels are: $* * * p<0.01, * * p<0.05, * \mathrm{p}<0.1$ 
Table 4: Effects of Fund Balances on Total Expenditure in "Downturn Years" and "Upturn Years"

Heckman Two-Stage Sample Selection Models; DV are Expenditure Gaps

\begin{tabular}{|c|c|c|c|c|c|c|c|c|}
\hline & \multicolumn{4}{|c|}{ Downturn Years (exp gap <0) } & \multicolumn{4}{|c|}{ Upturn Years (exp gap > 0) } \\
\hline & Coefficient & $\mathbf{Z}$ & Coefficient & $\mathbf{Z}$ & Coefficient & $\mathbf{Z}$ & Coefficient & $\mathbf{Z}$ \\
\hline Fund balance available ${ }_{t-1}$ & 0.003 & 0.995 & & & 0.021 & 1.631 & & \\
\hline$\%$ of fund balance available ${ }_{t-1}$ & & & -0.003 & -0.171 & & & $0.103 * *$ & 2.173 \\
\hline \multicolumn{9}{|l|}{ Revenue Sources } \\
\hline Property tax & 0.012 & 1.237 & 0.012 & 1.211 & $0.076 * * *$ & 3.577 & $0.079 * * *$ & 3.642 \\
\hline Sales tax & -0.003 & -0.103 & 0.003 & 0.092 & 0.001 & 0.014 & 0.015 & 0.226 \\
\hline Intergovernmental & $0.018 * *$ & 2.065 & $0.018 * *$ & 2.064 & $\mathbf{0 . 0 3 0} * * *$ & 3.130 & $\mathbf{0 . 0 3 0} * * *$ & 3.134 \\
\hline \multicolumn{9}{|l|}{ Economic Indicators } \\
\hline Personal income $(1,000)$ & 0.023 & 0.064 & 0.051 & 0.145 & -0.729 & -0.822 & -0.703 & -0.793 \\
\hline Unemployment rate & -0.133 & -0.821 & -0.134 & -0.830 & 0.253 & 0.390 & 0.292 & 0.452 \\
\hline \multicolumn{9}{|l|}{ Social Indicators } \\
\hline$\%$ of population under 18 & 0.066 & 0.185 & 0.042 & 0.118 & 0.596 & 0.571 & 0.553 & 0.533 \\
\hline$\%$ of population over 65 & 0.708* & 1.711 & $0.709 *$ & 1.713 & -0.372 & -0.404 & -0.296 & -0.320 \\
\hline Population $(1,000)$ & $0.100 * * *$ & 2.604 & $0.099 * * *$ & 2.596 & 0.013 & 0.132 & 0.020 & 0.192 \\
\hline Population squared & $\mathbf{- 0 . 0 0 0 1 * * *}$ & -2.732 & $-0.0001 * * *$ & -2.743 & 0.00001 & 0.065 & 0.0000 & -0.008 \\
\hline \multicolumn{9}{|l|}{ County Size(binaries) } \\
\hline Large & -3.019 & -1.219 & -2.931 & -1.186 & $-13.817 * *$ & -2.487 & $-14.750 * * *$ & -2.598 \\
\hline Medium & 0.236 & 0.122 & 0.347 & 0.181 & $-7.929 *$ & -1.699 & $-8.556 *$ & -1.799 \\
\hline Medium small & 2.359* & 1.951 & $2.407 * *$ & 2.006 & $-6.823 *$ & -1.787 & $-7.106 *$ & -1.836 \\
\hline Constant & $-30.042 * *$ & -2.468 & $-29.887 * *$ & -2.451 & 19.148 & 0.611 & 16.174 & 0.513 \\
\hline Wald $X^{2}$ & 806.27 & & 810.85 & & 441.34 & & 439.42 & \\
\hline$\left(\mathrm{P}>X^{2}\right)$ & 0.00 & & 0.00 & & 0.00 & & 0.00 & \\
\hline Log pseudo likelihood & -3924.82 & & -3925.22 & & -3569.61 & & -3568.79 & \\
\hline Test of indep. Eqns & 24.20 & & 24.40 & & 80.97 & & 81.50 & \\
\hline$\left(\mathrm{P}>X^{2}\right)$ & 0.00 & & 0.00 & & 0.00 & & 0.00 & \\
\hline Censored obs & 703 & & 703 & & 990 & & 990 & \\
\hline Uncensored obs & 990 & & 990 & & 703 & & 703 & \\
\hline
\end{tabular}

Note: Significance levels are: $* * * \mathrm{p}<0.01, * * \mathrm{p}<0.05, * \mathrm{p}<0.1$ 